\title{
Kartal urban regeneration project: challenges, opportunities and prospects for the future
}

\author{
A. Kocabas \\ Department of City and Regional Development, \\ Mimar Sinan Fine Arts University, Turkey
}

\begin{abstract}
The aim of this paper is to analyse the evolution of urban regeneration in the Kartal District in Istanbul and assess prospects, in the context of changing national and metropolitan policies and programmes. Therefore, the paper analyses the recent planning activities in the District, which include: the preparation of a strategic development framework prepared by John Thompson and Partners, working with District Municipality planners; an international urban design competition won by Zaha Hadid; and a formal 1:5000 Master Plan prepared by the GIMM. The outcomes of this planning and design activity are not yet clear. However, there is a danger that the proposed metropolitan subcentre will accommodate offices, hotels and housing for middle and higher income groups, in gated developments isolated from the surrounding poor neighbourhoods which will not benefit from all this investment. The paper concludes by outlining an alternative derived from the application of the principles of sustainable regeneration.

Keywords: urban and neighbourhood regeneration, sub-regional centre, strategic development framework, sustainable regeneration.
\end{abstract}

\section{Introduction}

Kartal is a District Municipality in the south-east sector of the Greater Istanbul Metropolitan Municipality (GIMM) on the Anatolian side of the city, fig. 1. The regeneration of Kartal is an important component of the evolving plans and programmes for the development of Istanbul as a world city. The current urban conditions in the municipality present both challenges and opportunities for policy makers. The aim of this paper is to analyse the evolution of urban 


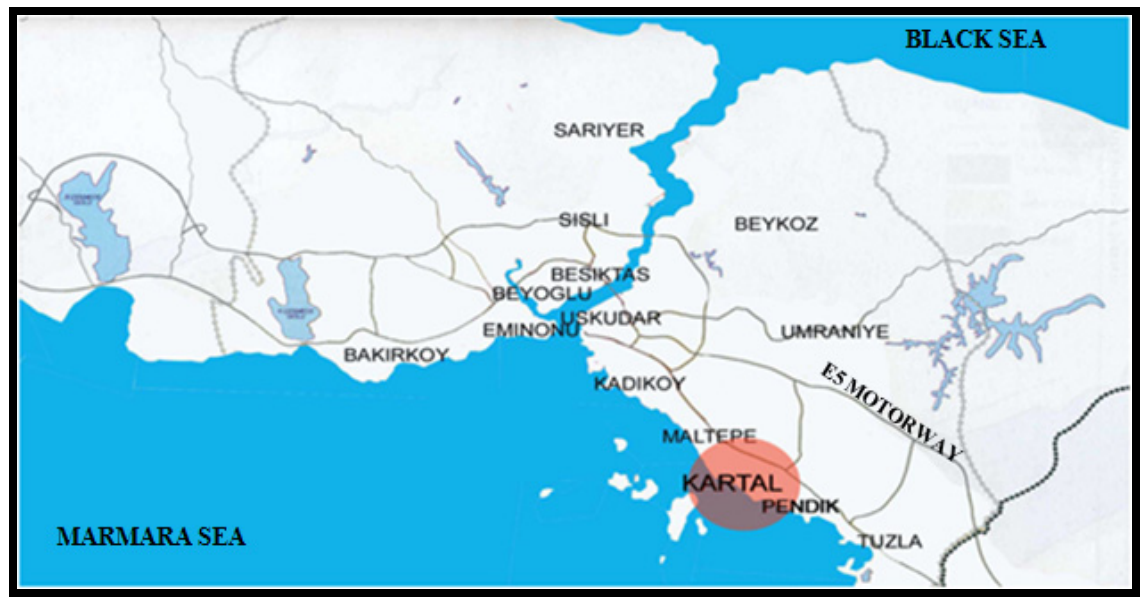

Figure 1: Location of Kartal District in Greater Istanbul Metropolitan Area (source: adapted from [1], p. 4).

regeneration in Kartal and assess prospects for the District's sustainable development as a sub-regional centre in the context of changing national and metropolitan planning policies and programmes.

The paper first analyses the consequences of the rapid urbanisation of Kartal in the 1950s and 1960s, which attracted migrants from Anatolia to work in the new factories, particularly in the burgeoning textiles sector. Economic liberalisation precipitated de-industrialisation from the mid 1980s onwards, a process that has been accelerated by the increasing impact of globalisation in the post-cold war era. These global economic dynamics have left a legacy of large areas of semi-derelict land in the midst of increasingly deteriorating poor quality neighbourhoods. The $21^{\text {st }}$ century challenge for decision makers and planners is to develop a process of sustainable urban regeneration that integrates urban economic development with the physical and social regeneration of deprived neighbourhoods, in ways which reduce the carbon footprint of the municipality. The response to this challenge is then critically reviewed. The Istanbul Master Plan identified Kartal as an area that needs major re-development to create a metropolitan sub-regional centre, as part of a metropolitan strategy for developing Istanbul as a polycentric world city. In this context, recent planning activities include: the preparation of a strategic development framework by John Thompson and Partners, working with District Municipality planners; an international urban design competition organised by the GIMM and won by Zaha Hadid; and a formal 1:5000 Master Plan prepared by the GIMM to provide an approved planning context for a major private sector led mixed use urban regeneration project. The outcomes of this planning and design activity are not yet clear, but there is a danger that the prestige mixed use development will be isolated from the surrounding poor neighbourhoods which will not benefit significantly from the creation of the new metropolitan sub-centre. The paper 
concludes by outlining an alternative approach derived from the application of the principles of sustainable regeneration.

\section{Explosive growth, de-industrialisation and the need for urban regeneration}

The growth of Kartal was part of the explosive growth of Istanbul from the 1970 s onwards through rapid industrialisation and massive migration from rural Anatolia, fig. 2. In two decades Istanbul's population grew from $2 \mathrm{~m}$ to $10 \mathrm{~m}$. As part of this growth Kartal's population increased from 25.000 to 210.000 between 1970 and 1990 and now stands at more than 500,000. From the late 1950 s, through the 1970 s and into the early 1980 s the state-led process of industrialisation stimulated increasingly rapid rural-urban migration. The mechanisation of agriculture was the main 'push factor' and the 'pull factor' was the increasing availability of jobs in the new and expanding urban industries, such as textiles and engineering. The rapid construction of a modern road network facilitated the migration.

For much of this phase urban growth was dominated by self-build gecekondu (literally translated as 'built overnight') development of mainly single storey dwellings, usually with a garden attached. This was illegal development on 'Treasury Land' (i.e. on land owned by the state) and as such had limited (initially illegal) access to basic services of water supply, sewage disposal, electricity etc. Periodically the government granted an amnesty, giving limited apartment ownership rights and improved access to services, often rather obviously in exchange for votes. Such amnesties inevitably led to further waves of gecekondu development $[2,3]$.

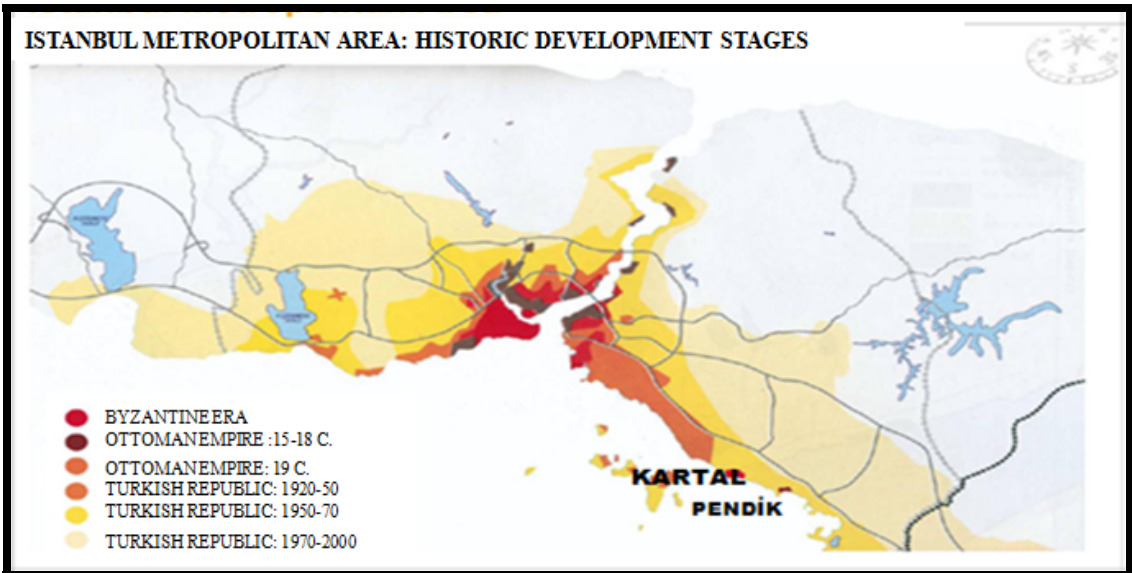

Figure 2: Growth of industrial and residential districts of Istanbul including Kartal (1950-1980) (source: adapted from [1], p. 12). 
The restoration of democracy after the $1980-83$ period of military rule was accompanied by the liberalisation of the economy and renewed economic growth which prompted further immigration, which was increasingly driven by the civil war in eastern Anatolia. But it remained beyond the capacity of the state to provide regulated housing. Thus much of the continuing population increase was accommodated in new neighbourhoods of illegal housing. However, a rapidly increasing proportion of these new housing units were in multi storey, concrete frame construction apartment blocks, built as speculative developments. The overall outcome of these urban growth processes was hundreds of neighbourhoods built to low standards of construction, with poor services and minimum standards. In Istanbul over $80 \%$ of the housing stock is illegal.

The 1980s also saw the first period of neighbourhood regeneration in Istanbul. The continuing and intensifying pressure for development, combined with the government granting gecekondu occupants vertical development rights, resulted in the redevelopment of many of the original squatter neighbourhoods. Thus in Istanbul groups of the original squatters (typically four or six) cooperated with small-scale constructors to demolish their single storey dwellings and redevelop their combined plots to produce a multi storey building containing ten to fifteen apartments. Typically each gecekondu 'owner' would receive an apartment to live in and one to rent out, with the balance of the apartments being sold by the constructor to recoup capital costs and provide a profit. This was known as the 'share of construction method' (yap sat), a market mechanism for the redevelopment of gecekondus - from single storey self build single dwellings to low quality apartments.

The contemporary urban fabric of Kartal is a product of this urbanisation process. A large proportion of the urban growth was accommodated in a huge swathe of development south-east from central Istanbul, through Kadikoy, Maltepe, Kartal and Pendik, along the east-west corridor of the E5 motorway and the rail link to Ankara. In Kartal industrial development was concentrated along the motorway and in a north-south corridor from the motorway to the Marmara shore. The original gecekondu housing was close by, but much of this has been redeveloped into typical multi storey, concrete frame construction apartment blocks, which together with those speculatively built in from the mid-1980s dominate the districts housing stock. A relatively small number of better quality neighbourhoods were developed to higher standards with full approvals. The legacy of three decades of explosive urban growth is increasingly obsolete urban fabric and services. Thus in the climate of modernization that has developed rapidly in recent years, policy makers have come to focus on the need to upgrade Istanbul's urban fabric. From the perspective meeting the needs of the economic restructuring of Turkish cities and improving social conditions, two issues are seen as increasingly pressing. The first is the need to upgrade deteriorating gecekondu neighbourhoods, in order to improve the image of the city, particularly to foreign investors, and to reduce the worsening social and spatial inequalities by providing better housing, education and employment opportunities to residents of poor neighbourhoods. The second is the need to create new sub-regional centres in strategic locations to meet the demands of 
the rapidly developing metropolitan economy for new office space and improved urban transportation. Increased prosperity is generating new demands for retail, leisure and cultural facilities, together with better quality housing to accommodate those who have secured better jobs and higher incomes.

However, poor quality urban development is not only obsolete; it is a threat to public safety and health. The explosive urbanisation process took place during a period of 'earthquake amnesia' when the earthquake threat had virtually been forgotten - Istanbul had not experienced a major earthquake since the end of the $19^{\text {th }}$ century. The result was that much of this rapid urban development was located on earthquake vulnerable land. The 1999 Marmara Earthquake and subsequent analysis dramatically redefined the problem of obsolete housing and urban infrastructure. Over 17,000 people were killed. The destruction or damage of 300,000 dwellings, buildings and infrastructure caused extensive economic losses, estimated by the World Bank to be over 6 billion USD [4]. Much of this damage was a direct consequence of the failure of the planning system to steer urban development away from high-risk areas, combined with the failure to implement building regulations to secure earthquake resistant construction. The decline of Kartal's traditional industries has left large areas of underused and semi-derelict former industrial land, which is concentrated in the north-south axis, fig 3 .

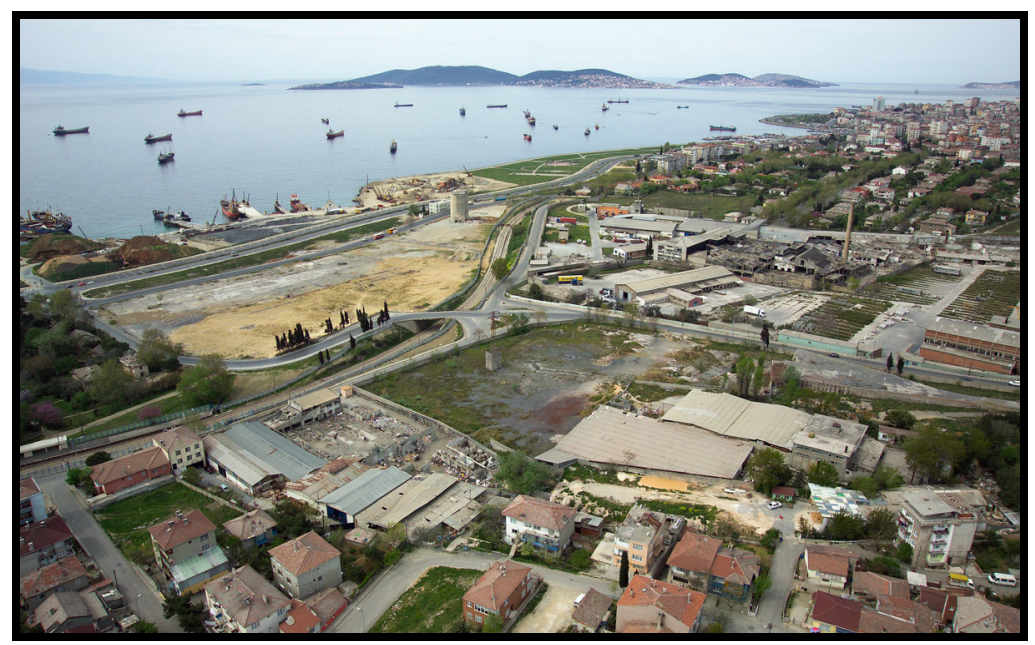

Figure 3: Underused and derelict former industrial land in north-south axis (source: [1], p. 9).

The new train link to central Istanbul and the nearby rapidly expanding Sabiha Gokcen international airport will dramatically improve the accessibility of this area. Thus this large site presents a real opportunity for major redevelopment as part of a process of modernising the urban economy of Kartal. But the neighbourhoods adjacent to or close to this area are in very poor condition and some are at risk of very serious earthquake damage. A sustainable 
urban regeneration process requires the integration of urban economic development with a programme of neighbourhood regeneration in ways which moves towards low carbon urbanisation, particularly by reducing carbon emissions from the building stock. Since the mid 2000s the future of Kartal has been the subject of increasing planning activity, which this paper now critically reviews.

\section{A transitional period of planning for sustainable urban regeneration}

Recent proposals for the future of Kartal have been developed through a top down planning process which gives little opportunity for local people to participate. This is the conventional approach in Turkey and is urgently in need of modernisation. In 2005 the AK Party (conservative-pro Islam) Mayor of Istanbul created the Istanbul Metropolitan Planning Centre (IMP) as a GIMM funded urban planning agency with the priority task of preparing a strategic plan to guide the $21^{\text {st }}$ century development of the city. The Plan was approved in 2007. A key issue was the unsustainable nature of the existing spatial structure of Istanbul. The largely unplanned rapid urbanisation had created a monocentric city of $12 \mathrm{~m}$ people. Commercial activities and tertiary sector employment were heavily concentrated in the expanded central business district (CBD) on the European side around the Golden Horn. This resulted in massive traffic congestion as people travelled in to work from the sprawling suburbs which had only small district centres with limited employment opportunities. A basic component of the strategy is to create a polycentric city by the development of a series of sub-regional centres, which would enable the city's economy to expand but in a way that reduced the pressures on the CBD and the greenbelt.

The 1/100.000 Environmental Order Plan designated Kartal to be developed as one such centre for major investment in service sector employment, tourism and recreation. Its location on the Anatolian side, rapidly improving communications with the metro line extension from central Istanbul and proximity to the new and rapidly expanding Sabiha Gokcen airport, together with the opportunities for re-development of underused former industrial land were key factors. As a regional sub-centre Kartal will provide new types of jobs which will replace those lost through the decline of traditional industries. This major upgrading of Kartal is supported by central government, in particular by the Prime Minister R. Tayyip Erdogan who is a former Mayor of Istanbul. This metropolitan planning process also identified some forty strategic locations for large scale regeneration, one of which was the north-south former industrial axis of Kartal.

In parallel the AK Party Mayor of Kartal District commissioned John Thompson and Partners (JTP) to prepare an informal and advisory Kartal Strategic Development Framework (SDF) in 2005 [5], in close collaboration with Municipal planning staff. It analysed the existing urban form, the planning policy context, the housing stock and demographic profiles, the earthquake threat, industrial restructuring and labour market issues. This identified the key 
challenges in creating a better future for Kartal. The overall aim was to enable the economy to grow as part of the growth of Istanbul to a world city, but in ways that improve the quality of life of its citizens by reducing social inequality, whilst at the same time improving the environment. This was to be realised through a dual strategy of integrated strategic economic development projects and a neighbourhood regeneration programme.

An integrated series of strategic projects was identified to realise the economic development potential of the Municipality. Several of these projects focussed on the redevelopment of the north-south corridor of underused, former industrial land and included: a Civic Plaza along the southern flanks of the E5 a new hospital and business park in high quality parkland landscape; and the New Town, a mixed use quarter, including high quality office and residential accommodation, a new shopping centre, a University and a hotel district, on a north-south axis from the Botanical Garden south to the Marina and the Waterfront - a water edge boulevard with major recreation and tourism facilities.

Housing and neighbourhood regeneration addresses the social inequality which is manifest in the poor neighbourhoods, especially those which are vulnerable to serious earthquake damage. The outline Kartal neighbourhood regeneration strategy used the readily available data to profile the condition of the housing stock to identify the scale and character of the need for housing-led regeneration. Almost half of Kartal's housing stock comprises illegal buildings in poor condition, which are occupied by poor people who cannot afford better accommodation. A major redevelopment programme is needed, in order to both increase the earthquake resilience of the housing stock and bring it up to modern standards. Of the 26,000 buildings in Kartal 13,800 (52\%) are legal - i.e. valid building permit, but:

- 12,850 (48\%) are illegal buildings - in 3 categories - no building permission, buildings constructed which did not comply with the approved project plans, and buildings which were constructed to comply with the approved plans but have since been illegally extended - often an additional storey; and

- 2,969 (11\%) are original gecekondu buildings 6000 dwellings - the homes of 16,000 people constructed to very low standards, 13 of the 20 neighbourhoods contain gecekondus often in areas with poor services.

The impact of the next earthquake was quantified: 4,800 (20\% of total) buildings will be heavily $(9 \%)$ or moderately $(11 \%)$ damaged in the next major earthquake (approximately 17,000 apartments) 2,400 citizens will be killed and 4,300 will be seriously injured unless the urban fabric is made more earthquake resilient; 19 out of the 20 Kartal neighbourhoods will be damaged, but to varying degrees.

Given these challenges the aims and objectives of the strategy were defined as shown in Figure 4 to take account of the priorities for dealing with the most earthquake vulnerable stock and the original gecekondu and avoided forced displacement through community-based neighbourhood regeneration. A 10 year demolition and house-building programme was developed and a programme and process for the preparation of neighbourhood regeneration action plans was prepared. 
- Make the Districts housing stock earthquake resilient:

- identify the buildings at most risk i.e. those that are likely to be very heavily damaged in the next earthquake;

- identify the numbers of the most risky buildings that are concentrated in the target neighbourhood regeneration areas and prepare a programme for the demolition of the more scattered buildings;

- identify the buildings that will need to be demolished in order to create the safety boulevards and evacuation areas;

- review design standards and enforcement procedures to ensure that all new dwellings are earthquake resilient; and

○ prepare the Housing Redevelopment Programme which will include both the neighbourhood regeneration programme and a programme fro the demolition of individual or small groups of risky buildings that are outside the target neighbourhoods.

- Improve the overall quality of the District's housing stock in a way that improves the housing conditions of the poorest families in the worst neighbourhoods through a community based approach that avoids gentrification:

- give first priority to the redevelopment of gecekondus;

- prioritise the demolition of all other buildings at risk of serious damage which are in low income areas; and

○ incorporate these dwellings in the Housing Redevelopment Programme.

- Improve the image of the District - modernise the housing stock as part of the process of making the District attractive to inward investment;

- Contribute to the provision of high quality housing to attract and retain higher income households;

- Improve the economic prospects of residents in Neighbourhood Regeneration Areas, by the creation/protection of local jobs and enabling access to jobs elsewhere in the District through vocational education and job training.

Source: Adapted from [5].

Figure 4: The aims and objectives of the neighbourhood regeneration strategy.

The Kartal Strategic Development Framework was published for consultation by the Mayor of Kartal. However, it was not taken forward because the central north-south axis was identified by IMP as one of the sites for an international competition to attract 'star' architects, fig. 5. In 2006 the Mayor of Istanbul decided to hold an international competition to generate development proposals for three strategic sites, one of which was in Kartal. Zaha Hadid won the competition with a highly conceptual urban design scheme, fig. 6. The large landowners in the area formed the Kartal Urban Regeneration Association which funded Zaha Hadid to develop the design concept into urban design proposals for the comprehensive re-development of the area. The GIMM then began the preparation of the formal 1:5000 Master Plan which will provide a component of the legal basis for the implementation of Hadid's redevelopment proposals. 


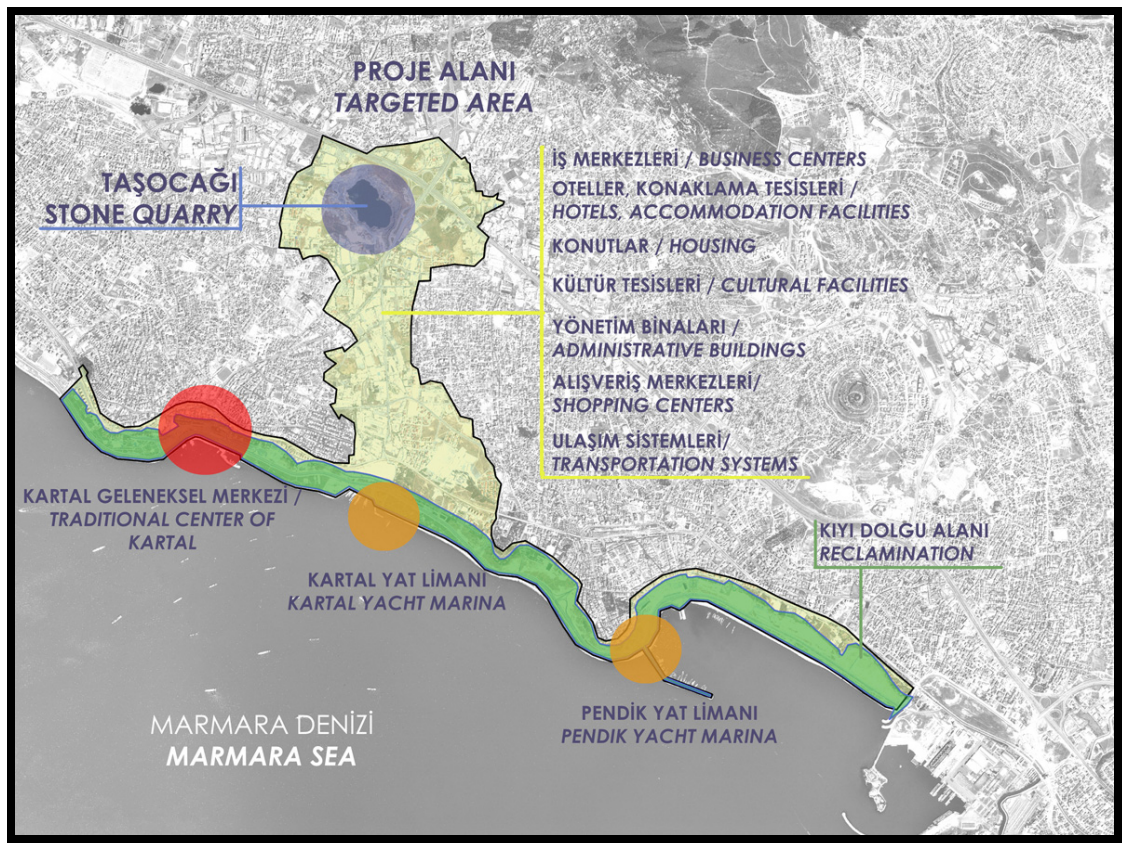

Figure 5: Kartal international competition site (source: [1], p. 8).

The final stage is the preparation of $1 / 1000$ scaled Implementation Plan which is the responsibility of the Kartal District Municipality.

This GIMM-IMP driven planning and urban design process attracted much criticism. The District Mayor supported the dual approach embodied in the advisory Kartal Strategic Development Framework, as he was sensitive to the need to develop an approach which combines economic development with neighbourhood regeneration.

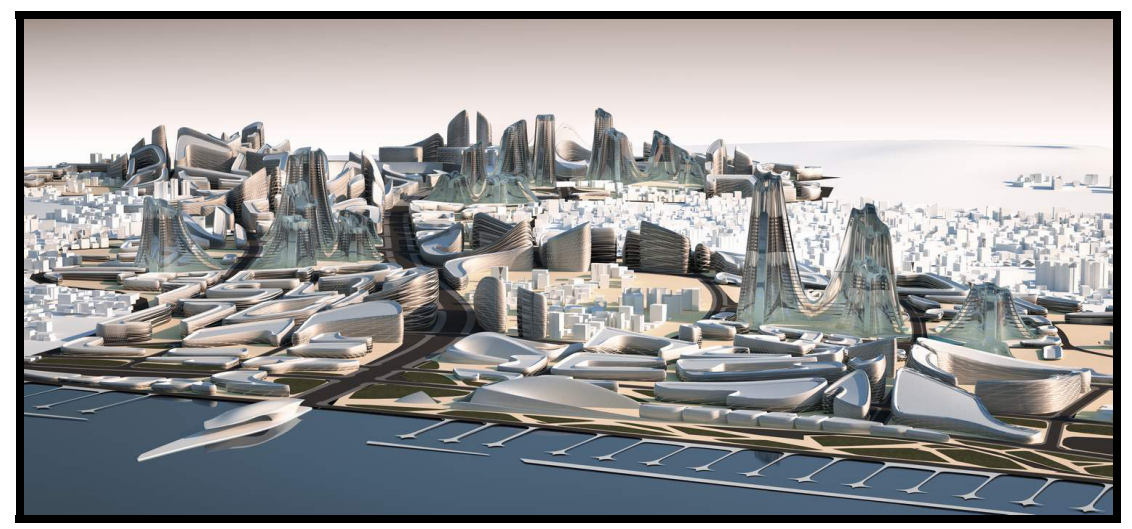

Figure 6: Z. Hadid conceptual scheme for the project area (source: [1], p.14). 
But the GIMM-IMP process made no attempt to link the evolving proposals for the north-south axis with the need to develop a strategy for the regeneration of the adjacent poor quality and deteriorating neighbourhoods. The Hadid project is being developed in isolation from the surrounding neighbourhoods. It remains to be seen whether the 1:5000 Master Plan addresses this issue. But this is not the only uncertainty. The 2009 elections resulted in a change to a CHP (social democratic) Mayor of Kartal who is opposed to the evolving redevelopment proposals for the central axis and wants to resources to be used to improve the conditions of the mass of Kartal citizens rather than concentrating efforts on one large-scale prestige projects which are expected to benefit only middle and higher income groups.

\section{An eco-oriented dual approach to urban regeneration}

Kartal needs a dual strategy which both supports the growth of the local economy and brings benefits to the low income groups in the poor neighbourhoods. Thus far the JTP advisory Strategic Development Framework has been 'left on the shelf'. Since the international competition the emphasis has been on planning the re-development of the prestige project area. There is continuing opposition to the project, now given voice by a new District Mayor. There is a danger that the prestige mixed use development will be isolated from the surrounding poor neighbourhoods which will thus not benefit significantly from the creation of a new metropolitan sub-centre. The new Mayor is responsible for the preparation of the 1:1000 Implementation Plan and he is not likely to give this a high priority, despite the importance of this project to the implementation of the Istanbul Master Plan proposals for a major new subcentre. The economic crisis is another factor that may well contribute to the stalling of the work on the prestige project.

This situation will present an opportunity to develop the second and neglected component of the dual approach - the preparation of a neighbourhood regeneration strategy. The District Mayor should take the lead on this by building on the outline neighbourhood regeneration strategy developed as part of the JTP strategy, as discussed above. An important step forward has already been taken by the Mayor who has initiated a process for funding and promoting a form of co-operative housing development process. This could be applied to secure the redevelopment of poor neighbourhoods where the share of construction process is not practical. There is an opportunity to develop a 'bottom up' community-based approach to neighbourhood regeneration through the creation of pilot projects to test and demonstrate the variety of approaches that will be needed to meet the needs of Kartal's heterogeneous poor neighbourhoods.

But it will also be important to continue the planning of the redevelopment of the north-south axis, but through a more participatory and inclusive process. Istanbul needs the new sub-centres proposed in the Metropolitan Master Plan to take some of the pressures of continued metropolitan economic development and to spread its benefits more widely. However, it will only be possible to 
implement this strategy if there is local support. Such support cannot be secured by the top-down imposition of the ideas of a 'star architect', funded by an organisation of major landowners, supported by the Metropolitan Municipality preparing plans effectively behind closed doors, with minimal public consultation. This process needs to be modified. Within the framework of the preparation of the 1/5000 Development Plan for the north-south axis, the type of development which will be promoted should be much more widely discussed to ensure and demonstrate that it benefits both the city of Istanbul as a whole (as a major component of developing Kartal as a regional sub-centre) and also a wide range of the citizens of Kartal.

Thus the modification of the planning process should introduce this bottomup dimension in order to deliberately spread more widely the benefits of the redevelopment over a 10-15 year period. Thus it should be shown that the revised proposals for the mixed used re-development should provide a range of jobs for a range of Kartals citizens:

- initially, there will be a large number of construction jobs - large scale projects should be linked to training programmes for local people to give them the necessary skills for modern construction work,

- the new service industries will need some relatively low skilled work in order to function - opportunities for people to work in restaurants and servicing offices,

- more highly skilled jobs will be created which many Kartal people who currently work on the European side will be able to secure and thus avoid long distance commuting, and

- training programmes can improve the skills of more local people and thus enable them to get the better paid jobs in the new economy of Kartal.

Finally, the strategic policy context for the regeneration of Kartal has changed since Turkey signed the Kyoto Treaty in 2009. In the context of the Copenhagen Conference and its aftermath, the Turkish government is giving increasing priority to reducing the country's carbon emissions. As in other developed and emerging countries, this will require the reduction of carbon emissions from the built environment, by the application of the principles of sustainable design such as improved insulation standards, more efficient heating systems, reducing the use of private cars and increasing the proportion of energy derived from renewable sources. The further planning of the redevelopment of the north-south axis and for the regeneration of Kartal's poor neighbourhoods will now have to incorporate in a strong environmental dimension. The successful development and implementation of an eco-oriented dual urban regeneration strategy will be a major contribution to a sustainable future for Kartal.

\section{Reference}

[1] Istanbul Metropolitan Planning Centre (IMP), Kartal Sub-Centre, KartalPendik Seafront Urban Transformation Project Competition Brief, 2006. 
[2] Keles, R., Urbanisation in Turkey, International urbanisation survey, the Ford Foundation, not dated.

[3] Tekeli, I., The development of the Istanbul Metropolitan Area: urban administration of planning, Istanbul: Kent Basimevi, 1994.

[4] Gibson, M. \& Kocabaş, A., 'Turkish planning at a crossroads: false dawn or vision of new era?', Kent ve planlama: geçmişi korumak geleceği tasarlamak, Ruşen Keleş'e Armağan Dizisi, ed. A. Mengi, 6(2), Ankara: İmge Kitabevi, pp. 165-201, 2007.

[5] Kartal Municipality and JTP, A vision and strategic development framework for Kartal, Kartal Belediyesi ve JTP, İstanbul, May 2006. 